\title{
Effect of Heat and Chemical Treatments on Physico-Chemical and Sensory Properties of Coconut Milk-Orange Beverage
}

\author{
D. C. Okafor ${ }^{1}$, B. C. Ijioma ${ }^{2}$, C. E. Ofoedu ${ }^{1}$, J. C. Nwosu ${ }^{3}$, E. U. Onyeka ${ }^{1}$, N. C. Ihediohanma ${ }^{1}$ and T. I. Okafor ${ }^{1}$ \\ ${ }^{1}$ Dept. of Food Science and Technology, Federal University of Technology, \\ Owerri, P. M. B. 1526 Owerri, Imo State, Nigeria \\ ${ }^{2}$ Department of Biology, Alvan Ikoku Fedral Colledge of Education
}

${ }^{3}$ Department of Home Economics, School of Vocational Education (Technical) Omoku

*Corresponding author's email: okafordamaris [AT] gmail.com

\begin{abstract}
The effect of heat and chemical treatments on physico - chemical and sensory properties of coconut milk-orange beverage was studied. Coconut milk $(\mathrm{CM})$ and single strength orange juice $(\mathrm{OJ})$ were prepared from coconut and orange fruits respectively. Orange Juice was used to replace coconut milk at 20, 40 and $60 \%$ levels and stabilized with carboxy methylcellulose to produce coconut milk-orange beverage. The beverage samples were in triplicate. A portion was treated with sodium benzoate, the second portion was pasteurized and the last portion was untreated (control). The three sets of samples were then packaged separately in glass bottles and stored under ambient temperature $\left(30 \pm 2^{\circ} \mathrm{C}\right)$. Physico-chemical and sensory evaluation were determined before they were stored for two weeks. The untreated fresh beverage samples contained higher amounts of fat, ash and protein but lower amount of crude fiber and carbohydrate. Ambient condition of storage effected increase in moisture but decrease in fat, protein and carbohydrate contents of all samples while ash and crude fiber remained unchanged. Chemically treated samples had the highest ( $p<0.5)$ Total Titratable Acidity value of $1.24 \%$ while control had $0.41 \%$. Based on the result findings of this research, 60: 40\% combination of Orange Juice and Coconut Milk is recommended. Again, the production of Coconut Milk-Orange Juice beverage has proved to be a viable option for addressing food security in Nigeria.
\end{abstract}

Keywords--- Beverage, coconut, orange, physic - chemical, sensory

\section{INTRODUCTION}

Malnutrition in form of protein, energy and micronutrient decencies is still a major public health problem in Nigeria. The high rate of micronutrient deficiencies in Nigeria has been attributed partly to poor dietary habits (Obizoba et al., 2004). Increased production and consumption of micronutrient rich foods would improve the micronutrients status of the Nigerian population (Egbekun and Akubor 2006). Fruits are good sources of micronutrients especially minerals and vitamin C. fruits form an important parts of the diets and are usually regarded as good foods (Falola et al., 2009). Orange (Citrus sinensis) fruits belong to the citrus genus and the fruits are either eaten fresh or made into orange juice. Orange juice is a good source of vitamin C, mineral and fibre (Olaofe and Akogun, 1990) and thus would be useful in bridging the micronutrients gap experienced in Nigeria and many other developing countries. Coconut milk is the white opaque liquid obtained from shredded coconut (Cocos nucifera L.) made by communiting or grating the flesh of the nut (with or without the addition of water) and pressing or dewatering the comminuted pulp. It is an important ingredient in Asian cuisine as well as in other parts of the world (Tangsuphom and Couplond, 2005). The composition of coconut milk varies according to variety, age, growing environment of the coconut, cultural practices, method of preparation, and the process condition used in extraction (the amount of water added and the temperature used in extraction) (Monera and Rosario, 1998). Typical compositions of coconut milk directly expelled from coconut kernel (without added water) are protein, $2.6 \%$ to $4.4 \%$; water, $50 \%$ to $54 \%$; lipids $32 \%$ to $40 \%$ and ash, $10 \%$ to $1.5 \%$ (Seow and Gwee, 1997).

Coconut milk is essentially an oil-in water emulsion, stabilized by naturally occurring proteins (globulins and albumins) and phospholipids (Lecithin and Cepphtin) (Silwinski, 2003). As an emulsion, coconut milk is not physically stable and is prone to phase separation. Natural coconut milk will separate into a cream and serum layer within 5 to 10 hours of manufacture (Tangsuphoom and Coupland, 2005).

The perishable nature of juices and beverages dictated immediate consumption within or less than 24 hours in warm climate and extended but still limited time in cooler environments, natural chilling or freezing was the only alternative to microbial modification of the juices (Bates at al, 2001). Some chemicals such as sulphur (IV) dioxide, benzoic aid, sorbic acids are added to fruits for preservation. Sodium benzoate and potassium sorbate are the preferred forms of chemical preservation given greater solubility of salt. Both function best at below pH 4.0. Benzoate and sorbate are often used together in combination with low temperature to extend the shelf life of minimally processed juice and beverage drinks. 
Inclusion of coconut milk in a coconut milk - orange beverage will provide a valuable source of protein and energy. On the other hand, orange juice will make good for the vitamin $\mathrm{C}$ deficiency of coconut milk, in addition to providing other essential vitamins, minerals and sugars. Also, the addition of orange juice can potentially improve the flavour of coconut milk. Information is lacking on the preparation, chemical composition, physical and sensory properties of coconut milk orange beverage. So to improve the utilization of coconut milk, orange juice was used to replace various levels of coconut milk in this paper. The objective of this paper are to investigate the potentiality of combining coconut milk and orange juice into a beverage, determine the nutritional content of the beverage, determine the effect of heat and chemical treatment on the nutritional content of the beverage and determine the stability of the beverage in terms of organoleptic and nutritional properties after two weeks of storage at ambient temperature.

\section{1} Source of Materials

\section{MATERIAL AND METHODS}

Mature coconut (Cocos nucifera) and mature ripened orange (Citrus sinensis) fruits used for the production of the beverage were obtained from Owerri main market. The chemicals used for the analysis were of analytical grade. All the equipment used both for the production and analyses are from the department of Science Laboratory Technology, Federal Polytechnic Nekede.

\subsection{Extraction of Orange Juice}

Orange juice was extracted as reported by Egbekun and Akubor (2006) from mature orange fruitsn and are washed with clean water. The cleaned oranges were manually peeled using a sharp knife. The juice was extracted using a domestic juice extractor. The resulting single strength orange juice was filtered. The resulting single strength orange juice was filtered using a double folded muslin cloth. The flow diagram for the production of single strength orange juice is shown in figure 1 .

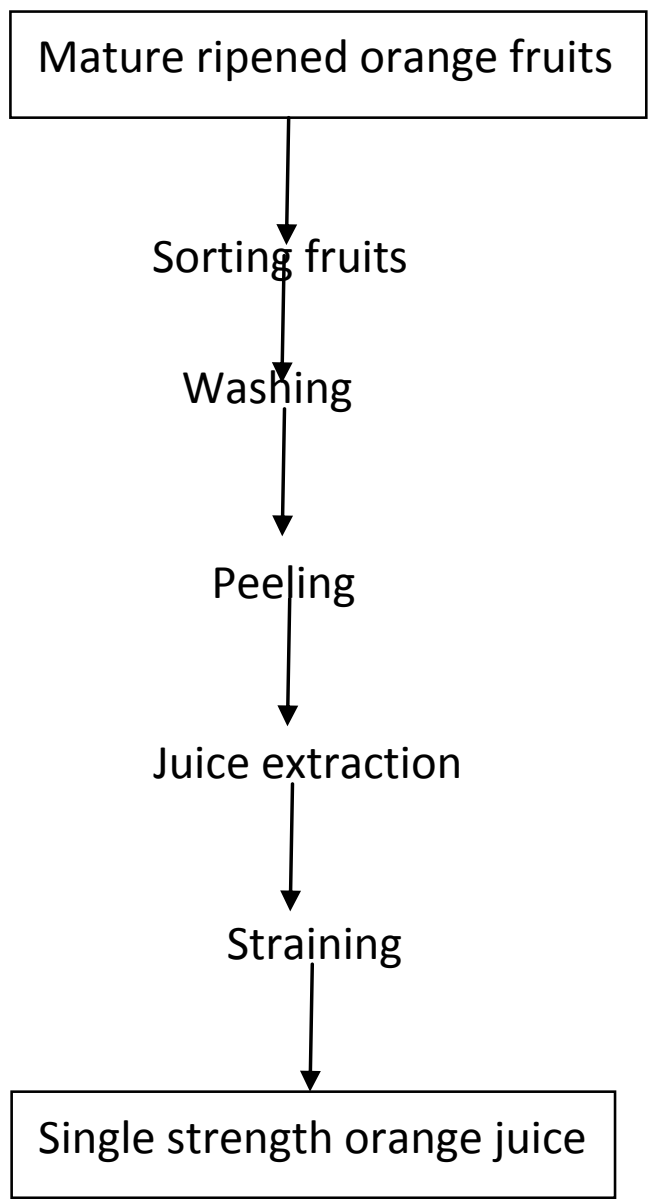

Figue 1: Flow Diagram for the Production of Single Strength Orange Juice 


\section{3}

\section{Extraction of Coconut Milk}

Coconut milk was produced as reported by Ogbechie (1998). The coconut fruits were dehulled manually by striking a rod on the coconut shell. The endosperm was removed from the coconut shell with the aid of a sharp knife. The brown skin on the endosperm was removed using a sharp knife. The brown skin on the white meat washed and weighed on an analytical weighing balance. The washed meat was manually grated using a plastic food grater. The grated white meat was soaked in hot water at temperature of $100^{\circ} \mathrm{C}$ for five minutes. The resulting slurry was filtered through double folded muslin cloth. The production process of coconut milk is illustrated in figure 2.

\subsection{Preparation of Stabilizer}

Stabilizer was prepared according to the manufacturer's direction. The stabilizer used was carboxyl methyl celluse (CMC) powder procured from Owerri main market, Imo state. Five grams $(5 \mathrm{~g})$ of the stabilizer was dissolved in twenty milliliters $(20 \mathrm{ml})$ of hot water $\left(100^{\circ} \mathrm{C}\right)$ and was properly stirred using a cleaning metal spoon. It was allowed to stand for five minutes.

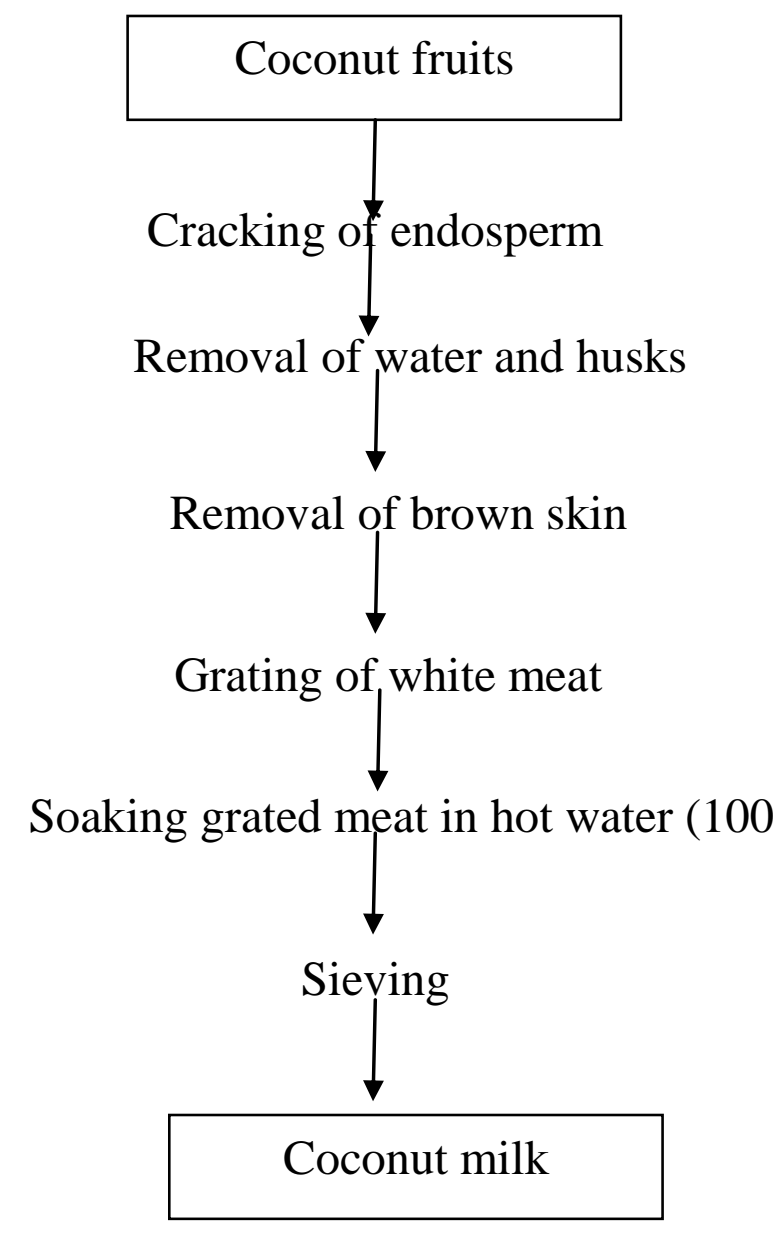

Figure 2: Flow Diagram for the Production of Coconut Milk

\subsection{Production of Stabilized Coconut Milk Orange Beverage}

Two hundred milliliters $(200 \mathrm{ml})$ of samples was used. Coconut milk $(80 \mathrm{ml}, 120 \mathrm{ml}$ and $160 \mathrm{ml})$ was mixed with orange juice $(120 \mathrm{ml}, 80 \mathrm{ml}$ and $40 \mathrm{ml})$ respectively in clean sterile plastic bowls. The resultant mixtures were stabilized with the already dissolved carboxy methyl cellulose (CMC) stabilizer and were sweetened with five grams (5g) sucrose. The samples were in triplicate, to produce a total of 9 samples and were divided into 3 set of samples. The first set $(\mathrm{CM} 80 \mathrm{ml}$ : OJ 120ml; CM 120ml: OJ $80 \mathrm{ml}$ and CM $160 \mathrm{ml}$ : OJ $40 \mathrm{ml}$ ) were treated with $0.25 \mathrm{~g} / 100 \mathrm{ml}$ sodium benzoate and coded $\mathrm{CPA}, \mathrm{CPB}$ and $\mathrm{CPC}$ respectively. The second sets of samples were pasteurized at $85^{\circ} \mathrm{C}$ for 20 minutes and thee were coded HTA, HTB and HTC while the third set of samples were untreated and taken as control and coded UTA, UTB and UTC. The three sets of beverage samples $(200 \mathrm{ml})$ were filled into sterile glass bottles (1CM head space). Rapid cooling of the pasteurized beverage samples was carried out by immersing in cold water (Figure 3 ). The processed beverage set 
of samples were then duplicated to produce 18 samples (treated and untreated). The first sets of 9 samples were used immediately for proximate and physic-chemical analyses while the remaining 9 samples were stored at ambient condition $\left(30 \pm 2^{\circ} \mathrm{C}\right)$ for two weeks.

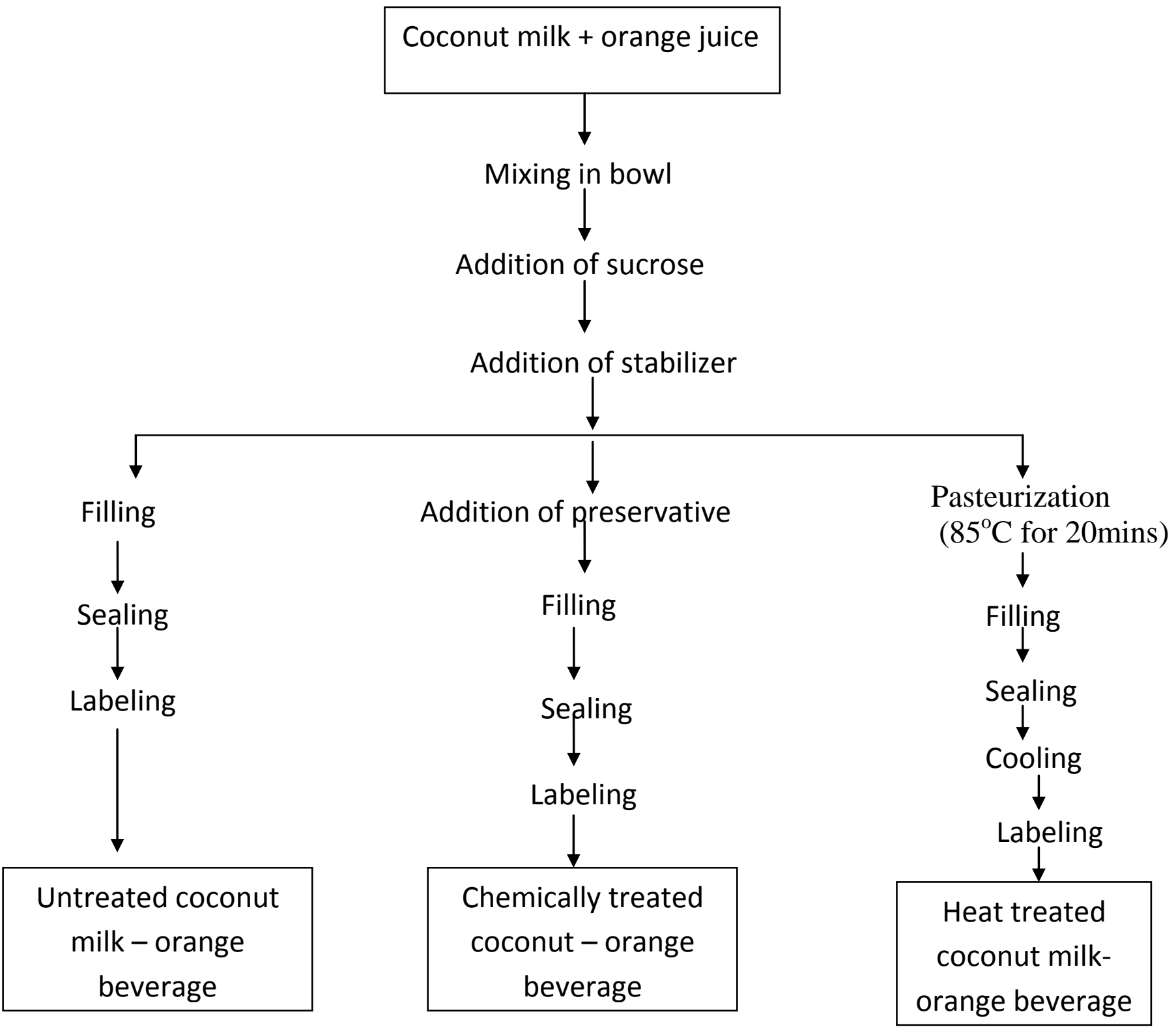

Figure 3: Production of untreated, heat and chemically treated Coconut Milk-Orange Beverage

\subsection{Analytical Methods}

Proximate analyses were carried out on moisture content ash, fat, protein, crude fibre and carbohydrate on the coconut milk and coconut milk-orange juice blends. The samples were further analysed for physic-chemical properties such as specific gravity, $\mathrm{pH}$, titratable acidity and refractive index. Sensory evaluation on colour, flavor, mouth feel and overall acceptability were carried out on the beverage samples. Subsequent analyses on these parameters were carried out on the samples for the second week.

\subsubsection{Determination of Moisture Content}

The A.O.A.C (1990) method was followed. Four grams of samples were weighed into dried and weighed crucible. The samples were put into gallenkamp moisture extractor oven at $105^{\circ} \mathrm{C}$ for three hours. The dried samples were removed from the oven and put into a desicator, allowed to cool and weighed. The sample was reheated, cooled and weighed until a constant weight was attained. The weight of the sample was calculated. The calculation for moisture content was thus made:

$\%$ moisture $=\underline{\text { Loss of weight of sample }} \times 100$

$$
\text { Weight of sample }
$$




\subsubsection{Determination of Ash Content}

The A.O.A.C (1990) procedure for ash content was followed. Four grams of sample was weighed into clean, dried and weighed crucible. The sample in the crucible was dried in the oven at $105^{\circ} \mathrm{C}$ for about three hours to reduce moisture content before being transferred into the muffle furnace at $55^{\circ} \mathrm{C}$ until the sample turned white and free of carbon. The sample was then removed from the furnace, cooled in a desicator, weighed until a constant mass obtained. The ash content was then expressed in percentage.

$$
\% \text { Ash }=\frac{\text { weight of ash }}{\text { Weight of sample }} \times 100
$$

\subsubsection{Determination of Fat Content}

A.O.A.C (1990) procedure was used. Two grams of sample was weighted into extraction tube, 10ml of concentrated hydrochloric solution was added to the sample in the extraction tube after which it was placed in a boiling water bath with constant occasional shaking until the solid particles dissolved and the mixtures became dark brown in colour. The tube was taken off and cooled rapidly. Ten mililitres $(10 \mathrm{ml})$ of alcohol was then added to the sample after cooling and shook thoroughly. 300ml of diethyl ether was added and shook vigorously. After complete separation, the ether layer was transferred to a weighed soxhlet flask and the solvent evaporated. The residual fat was dried in an oven at a temperature of $100^{\circ} \mathrm{C}$ for three hours until constant weight was achieved. The sample was cooled in a desicator and weighed. The percentage fat extracted was calculated thus:

$\%$ fat $=\frac{\text { weight of extracted fat }}{\text { Weigh of sample }} \times 100$

Weigh of sample

\subsubsection{Determination of Crude Fibre}

Two grams of sample and one gram of asbestos were put into a boiling $200 \mathrm{ml}$ of $1.25 \%$ sulpuric acid. This was boiled for 30mins. The boiled water was poured into Buchner funnel equipped with muslin cloth and secured with plastic band. The acid sample was poured and then filtered within ten minutes. The residue was washed with boiling water to free it of acid. It was returned in 30mins. Again it was filtered and washed with boiling water, then with $1 \%$ hydrochloric acid. It was again washed with boiling water to free it of petroleum ether. It was then drained and transferred to silica dish and dried in oven at $80^{\circ} \mathrm{C}$ to constant weight, cooled and weighed. Loss in ignition is crude fibre (A.O.A.C, 1990).

Percentage crude fibre was calculated thus:

$\%$ fibre $=\frac{\text { loss in weight }}{\text { Weight of sample }} \times 100$

\subsubsection{Determination of Crude Protein}

Protein content of samples was determined by the A.O.A.C (1990) procedure. Two grams of sample was put into a micro kjeldahi flask. Twenty five mililitres $(25 \mathrm{ml})$ of concentrated $\mathrm{H}_{2} \mathrm{SO}_{4}$ was added together with anti-bumping chips. The flask was heated using kjeldahl heating mantle until the initial black colour formed turned to light green colour. The flask was occasionally turned during heating to ensue uniform heating. The flask was covered with cotton wool and allowed to cool before distillation. Conical flask containing $50 \mathrm{ml}$ of $2 \%$ boric acid with four drops of added methyl-red indicator was placed under the condenser tip touched the liquid. The digest flask was mounted on the distiller and $80 \mathrm{ml}$ of $50 \%$ $\mathrm{NaOH}$ and $80 \mathrm{ml}$ of distilled water were added through the funnel. Cooling water was connected and the distiller was put on. A distillate of $150 \mathrm{ml}$ was obtained and titrated with $0.1 \mathrm{NHCI}$ to a pink end point.

The calculation for the crude protein was made thus:

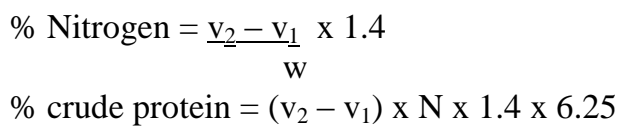

Where,

$\mathrm{W}=$ weight in gram of the test sample

$\mathrm{V} 1=$ volume in $\mathrm{ml}$ of hydrochloric acid solution required for the blank test

$\mathrm{V} 2=\quad$ volume $(\mathrm{ml})$ of hydrochloric acid solution required for the sample.

$\mathrm{N}=\quad$ Normality of hydrochloric acid.

\subsubsection{Determination of Carbohydrate}

This was done by difference percentage carbohydrate of the sample was calculated thus:

$\%$ carbohydrate $=100(\% \mathrm{MC}+\% \mathrm{~A}+\% \mathrm{P}+\% \mathrm{~F})$ 


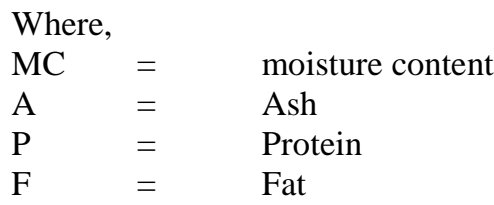

\subsubsection{Determination of $\mathbf{p H}$}

The $\mathrm{pH}$ as determined with a digital $\mathrm{pH}$ meter. This was done by weighing $20 \mathrm{ml}$ of sample into a breaker. The digital $\mathrm{pH}$ glass electrode was inserted into the sample in the beaker. This was done at ambient temperature of $30 \pm 2{ }^{\circ} \mathrm{C}$ and the value was noted and recorded.

\subsubsection{Determination of Total Titratable Acidity}

The total titratable acidity was carried out by titrating $10 \mathrm{ml}$ sample with $0.1 \mathrm{~N}$ sodium hydroxide phenolphthalein was used as the indicator. The proliferation of a pink colour indicated complete neutralization.

The equivalent weight of acid (lactic acid) was calculated and the equivalent titrable acidity was calculated thus:

$\%$ TTA $=\underline{\text { weight } \text { of the predominant acid (lactic acid) }} \times 100$

Volume of beverage sample

\subsubsection{Determination of Total Solid}

Total solid was calculated as follows:

Total solid $=100 \%$ - percent moisture content.

\subsubsection{Determination of Special Gravity}

The specific gravity of the samples was determined using a density bottle. A density bottle was weighed on a weighing balance and the value noted. Twenty mililitres $(20 \mathrm{ml})$ of distilled water was poured into the density bottle and weighed, the value noted are recorded. Twenty mililitres $(20 \mathrm{ml})$ of sample was then poured into the density bottle and weighed. The value recorded (A.O.A.C, 1990). The specific gravity of the samples was obtained thus:

Specific gravity $=\quad$ weight of sample in density bottle Weight of water in density bottle

\subsubsection{1}

\section{Determination of refractive index}

Refractive Index of the beverage samples were estimated using an Abbe refractometer.

\subsection{Sensory Evaluation}

The sensory evaluation was carried out to determine consumers' preference. Coconut milk orange juice blends (untreated, heat treated and chemically preserved) were evaluated for colour, flavor, taste, mouth feel and overall acceptability by twenty panelist as described by (Ihekoronye and Ngoddy, 1985). The samples were evaluated on a 9 point hedonic scale $(1=$ dislike extremely and $9=$ like extremely) in food science and Technology Laboratory. The panel members consisted of staff and students selected randomly from the university community. The beverage samples were presented in coded, indentical transparent bottle and a clean transparent serving cup was provided. Potable bottled water was provided for the panelists to rinse their mouth in between evaluations. In the questionnaire presented to the panelists, it was indicated that the coding system has nothing to do with the quality of the product. The raw scores were assembled and statistically analyzed.

\subsection{Statistical Analysis}

Analysis of variance was used to ascertain the significant differences between means. Least significant difference (LSD) was used to determine if there was significant Difference between the means. Significant was accepted at $\mathrm{p}<0.05$.

\subsection{Experimental Design}

Products (9 samples) x 9

Preservatives (CP and HT) $\quad$ x 2

Storage Time (2 weeks) $\quad \mathrm{x} 2$

Where,

$\mathrm{CP}=$ Chemical preservative (sodium benzoate)

$\mathrm{HT}=\quad$ Heat treatment (pasteurization at $85^{\circ} \mathrm{C}$ for $20 \mathrm{~min}$.)

Experimental design $=9 \times 2 \times 2$ factorial design. 


\section{RESULT AND DISCUSSION}

3.1 Effect of Preservative Treatments on Proximate Composition of Coconut Millk Orange Beverage The mean proximate composition of the beverage samples made from coconut milk and orange juice blends are presented in Table 1 . The moisture and carbohydrate content $(81.53 \%$ and $8.18 \%$ respectively) of chemically treated samples was higher than those of the heat treated and untreated samples. The higher moisture content was due to action of benzoic acid contained in sodium benzoate preservative. The crude protein content of the uuntreated sample (control), $1.28 \%$ was higher that of chemical ad heat treated sample. The fat content of all samples were relatively high and significantly $(\mathrm{p}<0.05)$ the same this shows that the inclusion of orange juice to coconut milk and the preservative treatment blends, The low level of protein content indelicate that the fruits are not good sources of the nutrient. Similarly, Obizoba et al. (2004) and Ogbonna et al (2013) observed a low Protein level of sour sop fruit juice and citrus fruits juices.

\begin{tabular}{|c|c|c|c|c|}
\hline & & ment & & \\
\hline$(\%)$ & CHEMICAL & HEAT & CONTROL & \\
\hline MOISTURE & $81.53^{\mathrm{a}}$ & $79.98^{\mathrm{a}}$ & $80.68^{\mathrm{a}}$ & 1.59 \\
\hline ASH & $0.97^{\mathrm{b}}$ & $1.30^{\mathrm{a}}$ & $1.35^{\mathrm{a}}$ & 0.08 \\
\hline PROTEIN & $1.13^{b}$ & $1.23^{\mathrm{a}}$ & $1.28^{\mathrm{a}}$ & 0.08 \\
\hline FAT & $8.53^{\mathrm{a}}$ & $8.78^{\mathrm{a}}$ & $8.37^{\mathrm{a}}$ & 2.50 \\
\hline CRUDE FIBRE & $1.77^{\mathrm{b}}$ & $3.40^{\mathrm{a}}$ & $2.03^{\mathrm{b}}$ & 0.64 \\
\hline CARBOHYDATE & $8.78^{\mathrm{a}}$ & $8.22^{\mathrm{a}, \mathrm{b}}$ & $7.31^{\mathrm{b}}$ & 0.94 \\
\hline
\end{tabular}

Means with the different superscripts are significantly different at $\mathrm{p}<0.05$

The beverage samples showed high carbohydrate values with beverage chemically treated having the highest (8.78\%) and it varied $(\mathrm{p}<0.05)$ with both pasteurized and untreated samples. This high carbohydrate suggests that chemically treated beverage could be a good source of energy for extra activities. As the inclusion level of orange juice of the beverage blends increases the moisture content decreases from $80.35-81.04$ (Table 2) the increase inclusion in other proximate compositions. There were no significant $(\mathrm{p}<0.05)$ differences in moisture, fat and carbohydrate content for all the beverage samples but significant $(\mathrm{p}<0.05)$ differences exist in ash protein and crude fibre contents.

Table 2: Effect of Level of Inclusion of Orange Juice on Proximate Composition of Coconut Milk - Orange Beverage

\begin{tabular}{|c|c|c|c|c|}
\hline \multicolumn{5}{|c|}{ LEVEL OF OJ INCLUSION (\%) } \\
\hline$(\%)$ & 20 & 40 & 60 & \\
\hline MOISTURE & $81.04^{\mathrm{a}}$ & $80.79^{\mathrm{a}}$ & $80.35^{\mathrm{a}}$ & 1.59 \\
\hline $\mathrm{ASH}$ & $1.08^{\mathrm{C}}$ & $1.22^{\mathrm{b}}$ & $1.32^{\mathrm{a}}$ & 0.08 \\
\hline PROTEIN & $1.12^{\mathrm{b}}$ & $1.22^{\mathrm{b}}$ & $1.29^{\mathrm{a}}$ & 0.08 \\
\hline FAT & $1.70^{\mathrm{b}}$ & $2.47^{\mathrm{a}}$ & $3.03^{\mathrm{a}}$ & 0.64 \\
\hline CRUDE FIBRE & $8.78^{\mathrm{a}}$ & $8.08^{\mathrm{a}}$ & $8.81^{\mathrm{a}}$ & 2.50 \\
\hline CARBOHYDATE & $8.00^{\mathrm{a}}$ & $8.08^{\mathrm{a}}$ & $8.23^{\mathrm{a}}$ & 0.94 \\
\hline
\end{tabular}

Means with the different superscripts are significantly different at $p<0.05$

$\mathrm{OJ}=$ Orange juice

\subsection{Effect of Preservative Treatment on Physico-Chemical Properties of Coconut Milk- Orange Beverage}

The mean physic-chemical properties of the beverage samples are presented in Table 3. Variations in the $\mathrm{pH}$ of their blends are significant $(\mathrm{p}<0.05)$. The $\mathrm{pH}$ value of the chemically treated sample was higher $(3.51)$ than that of the heat treated samples (3.17) and untreated (3.25). The iincrese in hydrogen ion concentration of the chemically treated beverage samples was properly due to the addition of sodium salt of benzoic acid and the dissociation of components acid of juice (Akpapunam et al., 1993). The high pH of the chemically treated sample resulted in increased percentagesof total titratable acidity as indicated in Table 3. However, the $\mathrm{pH}$ levels of beverage sample indicate that they are acidic. The total titratable acidity of the beverage samples was also low ranging from $0.41 \%-1.30 \%$. The total solids of the samples were relatively high but significantly $(\mathrm{p}<0.05)$ different. 
Table 3: Effect of Preservative Treatment on Physico-Chemical Properties of Coconut Milk-Orange Beverage

TREATMENT

PARAMETER

LSD

\begin{tabular}{lllll}
$(\%)$ & HEAT & CHEMICAL & CONTROL & \\
\hline $\mathrm{Ph}$ & $3.17^{\mathrm{b}}$ & $3.51^{\mathrm{a}}$ & $3.25^{\mathrm{b}}$ & 1.11 \\
TTA $(\%)$ & $0.77^{\mathrm{a}, \mathrm{b}}$ & $1.24^{\mathrm{a}}$ & $0.41^{\mathrm{b}}$ & 0.70 \\
TOTAL SOLID $(\%)$ & $19.75^{\mathrm{a}}$ & $17.81^{\mathrm{c}}$ & $18.96^{\mathrm{b}}$ & 0.58 \\
${ }^{\circ}$ BRIX & $1.34^{\mathrm{a}}$ & $1.34^{\mathrm{a}}$ & $1.33^{\mathrm{b}}$ & 0.00 \\
SPECIFIC GRAVITY & $1.02^{\mathrm{a}}$ & $1.04^{\mathrm{a}}$ & $1.20^{\mathrm{a}}$ & 0.08
\end{tabular}

Means with the different superscripts are significantly different at $\mathrm{p}<0.05$.

There were no significant differences in ${ }^{\mathrm{O}}$ Brix and specific gravity for all the samples this is in line with that reported by (Egbekun and Akubor, 2006). The effects of orange juice inclusion on the physico- chemical properties of coconut milkorange beverage are presented in table 4 . There were no significant $(\mathrm{p}<0.05)$ differences in $\mathrm{pH}$, Total titratable acidity, ${ }^{\circ}$ Brix and specific gravity of all the levels of orange juice inclusion but significant $(p<0.05)$ ) difference exists in the total solid. As the inclusion level of orange juice increased, the final product $\mathrm{pH}$ decreased from 3.41 to 3.20 and the titratable acidity increased from $0.067 \%-1.07 \%$ lactic acid this may have positive implications for the storage qualities of the coconut milk- orange beverage. The low $\mathrm{pH}$ would inhibit the growth of undersirable micro-organisms. Soymik with $\mathrm{pH}$ obtained for coconut milk-orange juice beverages is known to have enhanced shelf life stability (Banigo et al., 1986).

Table 4: Effect of Orange Juice Inclusion on Physico-Chemical Properties of Coconut Milk - Orange Beverage

PARAMETERS LEVELS OF OJ INCLUSION (\%)

\begin{tabular}{llll}
\hline 20 & 40 & 60 & LSD
\end{tabular}

\begin{tabular}{|c|c|c|c|c|}
\hline $\mathbf{P H}$ & $3.41^{\mathrm{a}}$ & $3.32^{\mathrm{a}}$ & $3.20^{\mathrm{b}}$ & 0.11 \\
\hline TTA (\%) & $0.67^{\mathrm{a}}$ & $0.78^{\mathrm{a}}$ & $1.07^{\mathrm{a}}$ & $0.7^{0}$ \\
\hline Total Solid (\%) & $18.02^{\mathrm{c}}$ & $18.84^{\mathrm{b}}$ & $19.65^{\mathrm{a}}$ & 0.58 \\
\hline BRIX & $1.34^{\mathrm{a}}$ & $1.34^{\mathrm{a}}$ & $1.34^{\mathrm{a}}$ & 0.00 \\
\hline $\begin{array}{l}\text { SPECIFIC } \\
\text { GRAVITY }\end{array}$ & $1.01^{\mathrm{a}}$ & $1.02^{\mathrm{a}}$ & $1.05^{\mathrm{a}}$ & 0.08 \\
\hline
\end{tabular}

Means with the different superscripts are significantly different at $\mathbf{p}<0.05$.

\section{OJ =Orange Juice}

The specific gravities of the beverages sample were similar to 1.02 - 1.0332 reported for cow's milk (Ihekoronye and Ngoddy, 1985). Abeverage sample with such specific gravity would be smooth in the mouth when drinking (Banigo et al., 1986). Specific gravity measurement is used in characterizing juice, beverages and other products as it is linked to the concentration soluble solids present in such material (Egbekun and Akubor, 2006).

\subsection{Effect of Pre-Treatments on the Sensory Properties of the Beverage.}

Sensory properties of food in any experimental study of food production is necessary since sensory properties constitute intrensic factors which are easily perceived or assessed by a consumer before a food is deemed acceptable for 
consumption (Umunnakwe, 1991). The sensory properties considered are colour, taste, flavour, mouthfeel and overall acceptability. The mean sensory scores of coconut milk -orange juice blends of treated and untreated samples are presented in Table 5.

Table 5: Mean Sensory Scores For Treated And Untreated Coconut Milk -Orange Juice Beverage

\begin{tabular}{llllll}
\hline \multicolumn{5}{c}{ SAMPLE } & \multicolumn{3}{c}{ SENSORY PARAMETERS } \\
\hline & COLOUR & TATSTE & FLAVOUR & MOUTHFEEL & OVERALL ACCEPTABILITY \\
HTA & $8.4^{\mathrm{a}}$ & $7.6^{\mathrm{a}}$ & $7.9^{\mathrm{a}}$ & $8.2^{\mathrm{a}, \mathrm{b}}$ & $7.5^{\mathrm{b}}$ \\
HTB & $7.9^{\mathrm{a}}$ & $6.7^{\mathrm{a}}$ & $7.3^{\mathrm{b}}$ & $7.7^{\mathrm{b}}$ & $7.3^{\mathrm{b}}$ \\
HTC & $7.2^{\mathrm{a}}$ & $7.3^{\mathrm{a}}$ & $7.4^{\mathrm{b}}$ & $8.1^{\mathrm{b}}$ & $7.5^{\mathrm{b}}$ \\
CTA & $7.7^{\mathrm{a}}$ & $6.3^{\mathrm{a}}$ & $7.0^{\mathrm{b}}$ & $7.4^{\mathrm{b}}$ & $7.5^{\mathrm{b}}$ \\
CTB & $6.2^{\mathrm{a}}$ & $7.0^{\mathrm{a}}$ & $7.3^{\mathrm{b}}$ & $8.1^{\mathrm{b}}$ & $7.9^{\mathrm{a}, \mathrm{b}}$ \\
CTC & $7.3^{\mathrm{a}}$ & $8.1^{\mathrm{a}}$ & $7.0^{\mathrm{b}}$ & $8.3^{\mathrm{a}}$ & $8.2^{\mathrm{a}}$ \\
UTA & $8.0^{\mathrm{a}}$ & $7.3^{\mathrm{a}}$ & $8.5^{\mathrm{a}}$ & $8.2^{\mathrm{a}, \mathrm{b}}$ & $6.7^{\mathrm{c}}$ \\
UTB & $8.2^{\mathrm{a}}$ & $7.6^{\mathrm{a}}$ & $8.1^{\mathrm{a}}$ & $8.0^{\mathrm{b}}$ & $7.2^{\mathrm{b}}$ \\
UTC & $7.7^{\mathrm{a}}$ & $7.3^{\mathrm{a}}$ & $7.8^{\mathrm{a}}$ & $8.0^{\mathrm{b}}$ & \\
\hline
\end{tabular}

Mean within the same column with different superscript are significantly different at $\mathrm{P} \leq 0.05$.

\section{KEYS}

HTA: Heat Treated 50\% Coconut Milk $+50 \%$ Orange Juice

HTB: Heat Treated $60 \%$ Coconut Milk $+40 \%$ Orange Juice

HTC: Heat Treated $80 \%$ Coconut Milk $+20 \%$ Orange Juice

CPA: Chemically Preserved 50\% Coconut Milk + 50\% Orange Juice

CPB: Chemically Preserved 60\% Coconut Milk $+40 \%$ Orange Juice

CPC: Chemically Preserved $80 \%$ Coconut Milk $+20 \%$ Orange Juice

UTA: Untreated 50\% Coconut Milk $+50 \%$ Orange Juice

UTB: Untreated $60 \%$ Coconut Milk $+40 \%$ Orange Juice

UTC: Untreated $80 \%$ Coconut Milk $+20 \%$ Orange Juice

The result of sensory evaluation showed that the beverage samples recorded high acceptable mean score for all the sensory parameters. There were no significant difference $(\mathrm{P} \leq 0.05)$ in colour, taste and mouthfeel for all the samples treated and untreated. However, there were significant differences in flavour and overall acceptability at 5\%. However, the flavour scores increased from 7.8 for the untreated beverage containing $20 \%$ Orange Juice to 8.5 for that containing $50 \%$ orange juice. Regarding the overall acceptability, all beverages containing $40-50 \%$ orange juice did not differ significantly $(\mathrm{P} \leq 0.05)$ in heat treated and chemically preserved samples. Hence, the contribution made by the orange juice component of the beverage improved the overall acceptability.

\subsection{Effect of Storage Time on the Proximate Composition and Physic-Chemical Properties}

After two weeks of storage at ambient temperature, a fresh analysis was conducted on all beverage samples heat treated (pasteurized), chemically preserved (preservation with sodium benzoate) and untreated. For all sample a great reduction in fat and protein contents were observed (table 6). This signifies that there is a continual biological or chemical changes taking place in the product at higher rate. There were no significant differences in ash, and crude fibre contents but a slight difference was observed in moisture and carbohydrate contents of all the beverage samples.

Result of storage stability test show that there was a gradual decrease in the $\mathrm{pH}$ value for the all beverage samples stored under ambient temperature which resulted to decrease in titratable acidity of the beverages stored under ambient condition (Table 7). This indicated that more acids were produced at higher temperature as a result of fermentation. This was in accordance with the finding of Abbo et al. 2006). The total titratable acidity of samples treated with sodium benzoate was found to be stable throughout the storage period while other titarable acidity changes as seen in Table 7 . Samples treated with sodium benzoate give what was best result in total titratable acidity. The increase in total titratable acidity of the beverages may be due to organic acid degradation. 
Table 6: Effect of Storage Time on Mean Proximate Composition of Coconut Milk-Orange Beverage

\section{TREATMENT}

PARAMETERS

\begin{tabular}{|c|c|c|c|c|c|c|c|}
\hline \multirow[t]{2}{*}{ PARAMETER } & & & & & & & \multirow[t]{2}{*}{ LSD } \\
\hline & $\mathrm{HT}_{1}$ & $\mathbf{H T}_{2}$ & $\mathbf{C P}_{1}$ & $\mathbf{C P}_{2}$ & $\mathbf{U T}_{1}$ & $\mathbf{U T}_{2}$ & \\
\hline MOISTURE & $79.98^{c}$ & $81.00^{\mathrm{b}}$ & $81.53^{b}$ & $83.00^{\mathrm{a}}$ & $82.79^{a}$ & $82.79^{a}$ & 0.93 \\
\hline $\mathrm{ASH}$ & $1.30^{\mathrm{a}}$ & $1.32^{\mathrm{a}}$ & $0.97^{\mathrm{b}}$ & $0.95^{\mathrm{b}}$ & $1.35^{\mathrm{a}}$ & $1.35^{\mathrm{a}}$ & 0.08 \\
\hline CRUDE FIBRE & $3.40^{\mathrm{a}}$ & $1.01^{\mathrm{c}}$ & $1.77^{\mathrm{b}}$ & $0.85^{\mathrm{c}}$ & $2.03^{c}$ & $1.03^{\mathrm{c}}$ & 0.69 \\
\hline Fat & $8.78^{\mathrm{a}}$ & $7.03^{b}$ & $8.53^{\mathrm{a}}$ & $4.75^{\mathrm{c}}$ & $8.37^{\mathrm{a}, \mathrm{b}}$ & $6.95^{\mathrm{b}}$ & 1.43 \\
\hline Protein & $1.23^{\mathrm{a}}$ & $1.01^{\mathrm{c}}$ & $1.13^{\mathrm{b}}$ & $0.85^{\mathrm{c}}$ & $1.28^{\mathrm{a}}$ & $1.03^{\mathrm{b}}$ & 0.05 \\
\hline Carbohydrate & $8.22^{\mathrm{c}, \mathrm{d}}$ & $9.63^{c}$ & $8.78^{c}$ & $10.44^{\mathrm{a}}$ & $7.88^{\mathrm{d}, \mathrm{a}}$ & $7.88^{\mathrm{d}, \mathrm{e}}$ & 0.05 \\
\hline
\end{tabular}

Mean with the different superscripts are significantly different at $\mathrm{P} \leq 0.05$

KEYS

HT1: $\quad$ Mean Heat Treated Samples (Day zero)

HT2: $\quad$ Mean Heat Treated Samples (Day zero)

CP1: $\quad$ Mean Chemically Preserved Samples (Day zero)

CP2: $\quad$ Mean Chemically Preserved Samples (Day zero)

UT1: Mean Untreated Samples (Day zero)

UT2: Mean Untreated Samples (Day zero)

Table 7: Effect of Storage Time on the Physiochemical Properties of Coconut Milk-Orange Beverage

\section{TREATMENT}

\begin{tabular}{|c|c|c|c|c|}
\hline PARAMETERS & HEAT & CHEMICA & CONTROL & LSD \\
\hline 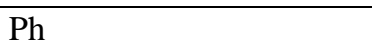 & $3.10^{\mathrm{b}}$ & $3.14^{\mathrm{a}}$ & $3.08^{\mathrm{b}}$ & 0.11 \\
\hline TTA $(\%)$ & $0.771^{\mathrm{a}, \mathrm{b}}$ & $1.02^{\mathrm{a}}$ & $0.42^{\mathrm{b}}$ & 0.70 \\
\hline TOTAL SOLID (\%) & $19.00^{\mathrm{a}}$ & $18.87^{\mathrm{c}}$ & $17.62^{b}$ & 0.58 \\
\hline 0 BRIX & $1.34^{\mathrm{a}}$ & $1.34^{\mathrm{a}}$ & $1.33^{b}$ & 0.00 \\
\hline SPECIDIC GRAVITY & $1.01^{\mathrm{a}}$ & $1.00^{\mathrm{a}}$ & $1.00^{\mathrm{a}}$ & 0.08 \\
\hline
\end{tabular}

Mean with the different superscripts are significantly different at $\mathrm{P} \leq 0.05$

At the end of the storage period, result showed that all samples stored under ambient condition were not preserved irrespective of the treatments given to the beverage samples and packaging material used in storing them that is the temperature throughout the storage period. The result did not fall within the standards given by the Nigerian industrial standards for fruit juices and beverages (NIS 377: 1997). The reason for the instability in physical properties and chemical composition of the treated and untreated beverage sample stored at ambient temperature is due to the relatively high temperature effect which may have facilitated the biochemical transformation of fat, protein and carbohydrate as reported by (Falola etal., 2009).

\section{CONCLUSION AND RECOMMENDATION}

The combination of orange juice and coconut milk resulted in beverage with improved nutrients compared to their respective components. Among the preservative methods studied, it has been shown that coconut milk - orange beverage samples preserved with sodium benzoate retained most quality attributes samples and were generally acceptable. The use of coconut milk - orange beverage should be promoted because of its nutrient potential particularly its high carbohydrate and vitamin $\mathrm{C}$ contents. The beverage can easily be consumed by children and adults to increase nutrient intake and diversify diets. Such a beverage will be helpful in reducing nutritional problems related to protein/vitamin $\mathrm{C}$ deficiencies. Packaging of coconut milk-orange beverage in glass bottles with addition of preservative agents and storing them under refrigerated conditions is suggested in order to protect the beverage from quality deterioration and spoilage. It is also recommended that further studies are necessary to determine the effect of preservative methods and storage conditions on the chemical, microbiological and sensory qualities of the beverage to see if improvement will be made on bottled products stored under ambient, a temperature profile studies may also be initiated.

\section{REFERENCES}

- A.O.A.C (1990). Official Methods of Analysis. $15^{\text {th }}$ edn. Association of Official Analytical Chemicals. Washington D.C, USA. Pp 95-224.

- Abbo, E.S; Olurin, T.O and Odeyemi, G (2006). Studies on the Storage Stability of Sour-sop (Annona muncala L) juice. Africa Journal of Biotechnology. 5(9): 1808-1812. 
- Akpapunam, M.A; Mepba, H.D and Wakama, L.A (193). Effects of pasteurizing Times on the Qulity of Processed Pineapple Juice. Nigerian Food Journal. 11(1): 9-15.

- Banigo, E.O; Ihinoya, K.I and Ossai, G.E. (1996). Development of Soy Beverage for Nigeria. Nigerian food Journal. 4 (1): 53-64.

- $\quad$ Bates, R; Morris, J and Crandall, p (2001). Principles and practices of small and Medium scale fruit Juice processing. Food and Agricultural Organization BullentinRome. Pp. 146.

- $\quad$ Egbekun, M.K and Akubor, P.I (2006). Chemical Composition and sensory properties of Melon Seeds Milk orange Juice Beverage. Nigerian Food Journals. 24 (1): 42-49.

- Falola, A.O; Adesala, S.O and Agwimah, J.O (2009). Effect of Storage on Heat and Chemically Processed Casaba Melon (Cucumis melo var indonrus) Juice. Nigerian Food Journal. 27(2): 136 - 149.

- Ihekoronye, A.I and Ngoddy, P.O (1985). Integrated food Science and Technology for the Tropics. Macmillan Publishers, London. Pp. 131-135.

- Monera, O.D and Rosario, E.J (1998). Physic-Chemical Evaluation of the Natural Stability of Coconut Milk Emulsion. Ann. Tropical Res. 4(1): 47-54.

- Obizoba I. C; Nnam N. M and Otukoro J. E (2004) Nutrient composition of pineapple (Ananas cosmosus) and soursop (Annona muricata) juices. Nigerian Journal of Nutrition Science, 25 (1) 13-15

- Ogbechie, V.N (1998). Production and Evolution of pineapple- Flavoured Coconut Milk. B. tech. Thesis Food Sience and Technology, FUTO.

- Ogbonna, C. A.; Abuajah, I. C., and Ekpe, E. G. (2013). A Comparative Study of the Nutritive Factors and sensory acceptance of Juices from Selected Nigerian Fruits. Hrvatski časopis za prehrambenu tehnologiju, biotehnologiju i nutricionizam, 8(1-2), 47-51.

- Olaofe, O and Akogun, O.O (1990). Mineral and Vitamin C Contents and their Distribution in some Fruits Nigerian Food Journal. 8(1): 111-115

- $\quad$ Seow, C.C and Gwee, C.N (1997). Coconut Milk. Chemistry and Technology. Inti J. Food sci. Technol. 32(3): 189-201.

- Silwinski, E.L and Roubos, P.J (2003). Effects of Heat on Physicochemical Properties of Whey ProteinStabilized emulsions. Journal of Applied Science 31(4) 231-242.

- Tansuphoom, N and Coupland, J.N (2005). Effect of Heating and Homogenization on the Stability of Coconut Milk Emulsions. J. Agric. Food Chem. 8(1): 317-321.

- Umunnakwe, K.E (1991). Effect of processing methods, packaging and Storage Temperature on the Quality of Soymilk. B. Tech. Thesis. Food Science and technology, FUTO. 